\title{
Bird conservation in the Alpilles, Southern France
}

\author{
Lisbeth Zechner
}

Keywords: Natura 2000, bird species, habitat management, stakeholder involvement

\section{Abstract}

Situated in Southern France, the hills of the Alpilles feature a central limestone massif and are recognized for the diversity of their habitats and landscapes, which include forest and garrigue, rocky habitats, dry grasslands, wetlands and traditional farmland. The LIFE Alpilles project (2013-2019) was developed and managed by the Alpilles Regional Natural Park. The project sought to favour 13 bird species found in this range, some of which, such as Bonelli's Eagle and the Egyptian Vulture, are among the rarest and most threatened species in France. The project's undertakings are focused as much on the promotion of human activities, including tourism, agriculture and livestock farming, which contribute to the presence of these species in the Park, as on the conservation of birdlife itself.
Profile

Protected area

Alpilles Regional

Natural Park/Natura

2000 site

Mountain range

Massife des Alpilles,

France

\section{The Alpilles (Small Alps) in Southern France}

The hills of the Alpilles are located in Southern France, in the region Provence-Alpes-Côte d'Azur (PACA) (see Figure 2), bordered by the river Rhône in the west and the river Durance in the east. Given the status of Regional Natural Park (RNP) in 2007, this small Mediterranean territory of 51000 ha features a central limestone massif rising to $498 \mathrm{~m}$. Almost half of the surface area is agricultural land. 50000 people live in the Park or adjacent to it. The Alpilles are situated between two other RNPs, the Camargue in the southwest and the Luberon in the east, and are recognized for the diversity of their habitats and landscapes, which include forest and shrubland (garrigue), rocky habitats, dry grasslands, wetlands and traditional farmland. The mosaic of different habitats is home to a particularly rich and exceptional bird community and biodiversity. Moreover, this is also an innovative and economically active territory. As in many rural areas, the natural heritage of the Alpilles today faces a range of pressures due to changes in land ownership and agriculture, land use and urban development, as well as the increase of visitor numbers. At local level, the aim of the Park is to find solutions for integrating environmental issues into the various policies, projects and human practices or activities, such as leisure, farming and grazing.

\section{Rich and exceptional bird community}

About 250 bird species can be observed in the Alpilles. The Natura 2000 site (SPA, 27000 hectares) was designated for 27 bird species. The LIFE project focused on 13 of these species: Bonelli's Eagle (Figure 1), Lesser Kestrel, Egyptian Vulture (Figure 3), Short-toed Snake Eagle (Figure 4), Little Bus-

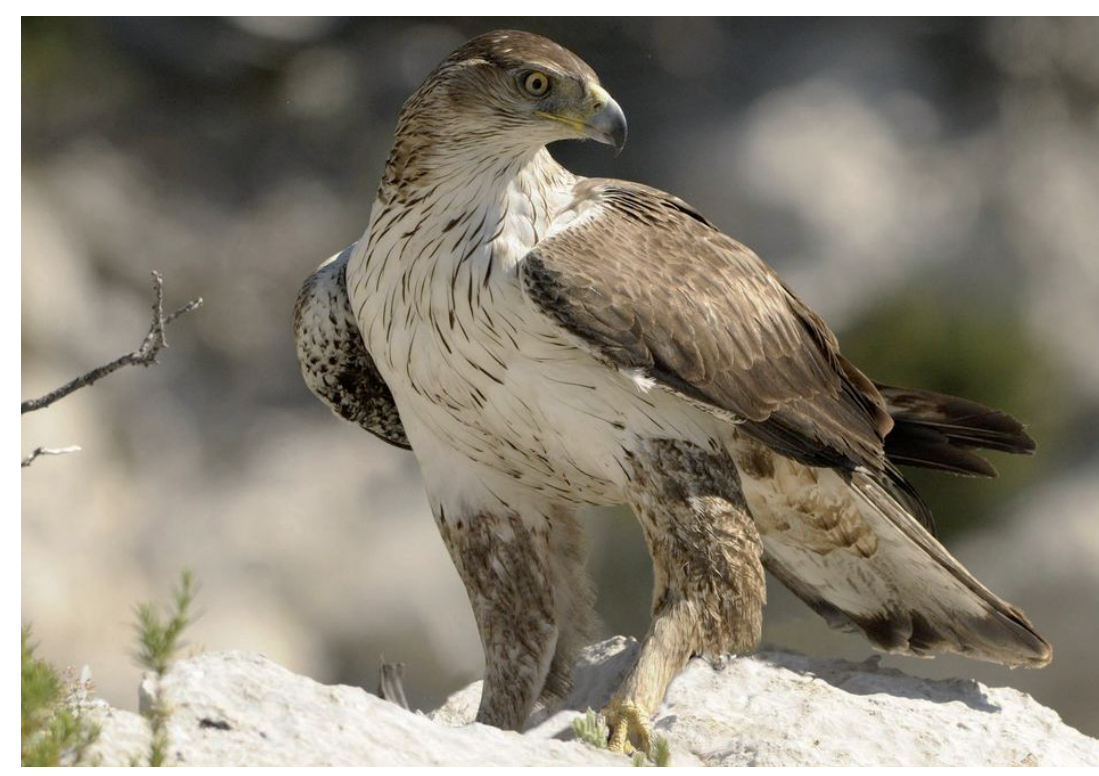

Figure 1 - Bonelli's Eagle - Aquila fasciata C CEN PACA / J.-C. Tempier

tard, Eurasian Eagle-Owl (Figure 5), Eurasian Scops Owl, European Roller (Figure 6), European Nightjar, Woodlark (Figure 7), Tawny Pipit, Dartford Warbler (Figure 8) and Ortolan Bunting. Bonelli's Eagle, the Little Bustard and the Lesser Kestrel were given priority in the LIFE+ Nature programme. In addition, French national conservation plans exist for Bonelli's Eagle, the Little Bustard and the Egyptian Vulture.

\section{LIFE + project Life des Alpilles}

The LIFE+ project Life des Alpilles aimed to demonstrate the close relationship between the presence of these 13 endangered bird species and traditional human activities. Specific objectives were to: 


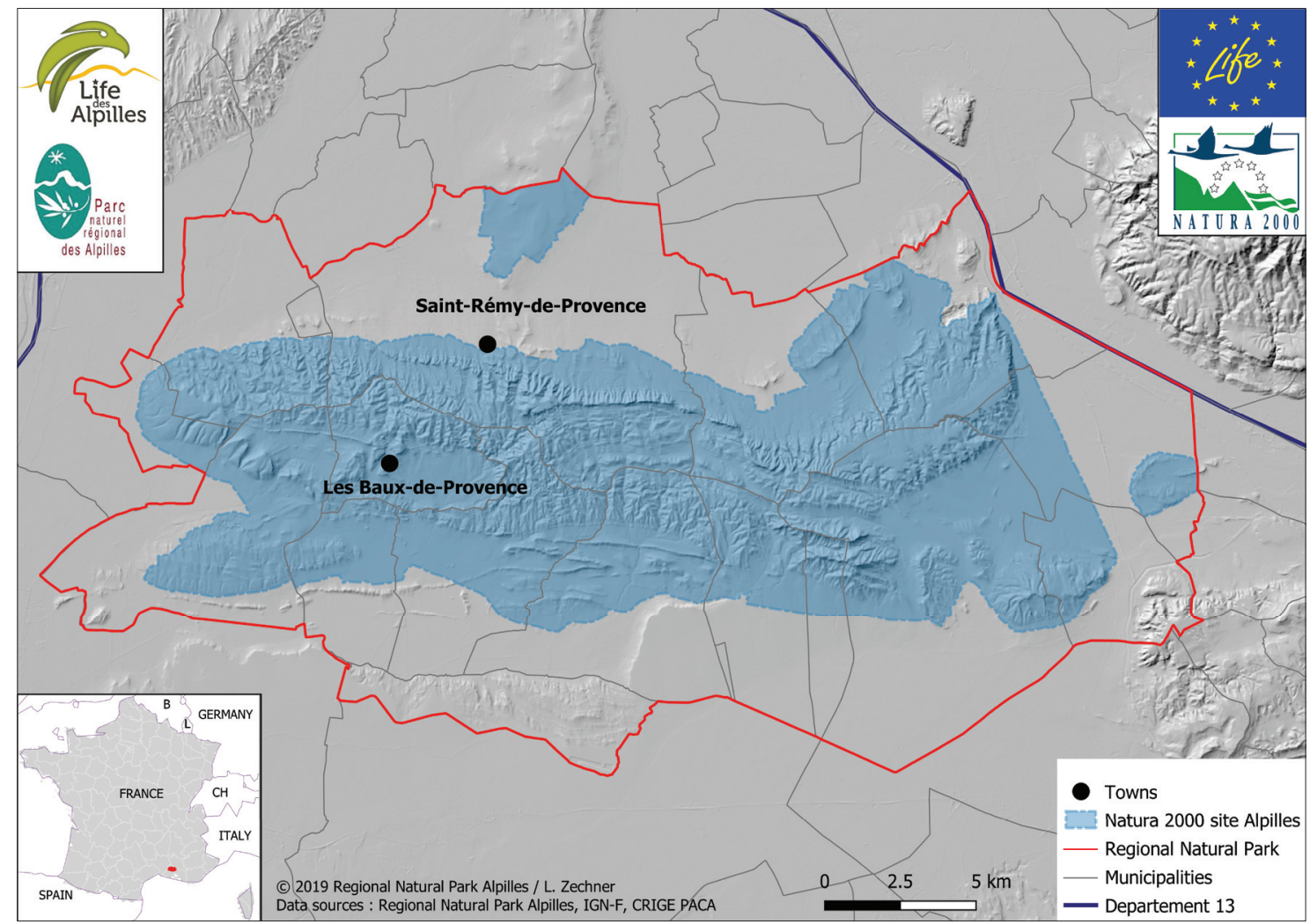

Figure 2 - Location of the Alpilles in Southern France (C) Alpilles PNR / L. Zechner

- strengthen the link between human activities and the preservation of bird biodiversity;

- maintain and restore the populations of 13 species listed in EU Birds Directives;

- increase public awareness of birds and their ecological needs (i.e. improve the understanding of ecological issues among local stakeholders);

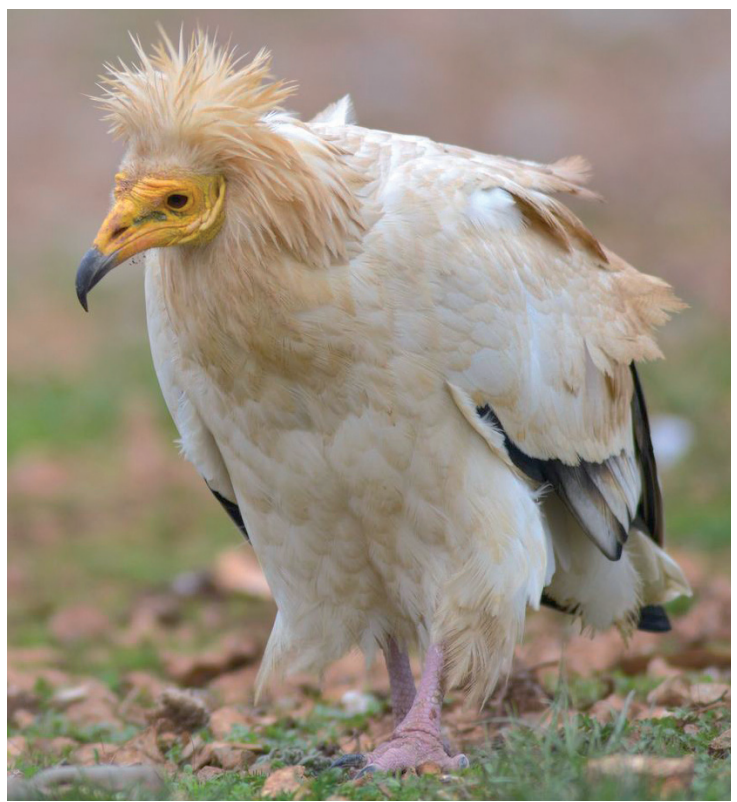

Figure 3 - Egyptian Vulture - Neophron perncopterus (C) B. Berthémy
- promote human activities and practices which favour the preservation of traditional landscapes and habitats in the Alpilles and that are socio-economically viable.

Between July 2013 and April 2019, the Alpilles RNP, as coordinating beneficiary, implemented the project and cooperated with six quite different associated beneficiaries, which reflect the broad scope of the project's actions:

- A Rocha France



Figure 4 - Short-toed Snake Eagle - Circaetus gallicus (C) B. Berthémy 
- CEN PACA (PACA Region Natural Areas Conservancy)

- CERPAM (Alps-Mediterranean Centre for Pastoral Studies and Projects)

- GIC des Alpilles (Alpilles Hunting Management Group)

- GOPVB (Les Baux Valley Professional Olivegrowers Group)

- LPO PACA (PACA branch of the national Birds Protection League).

2.4 million euros, of which $75 \%$ came from the European Union and 25\% from French funds (Sud Provence-Alpes-Côte d'Azur Region, Bouches-duRhône Department, Direction Régionale de l'Environnement, de l'Aménagement et du Logement Provence-Alpes-Côte-d'Azur (DREAL), as well as self-financing by the project's beneficiaries), were invested in preparing management plans and studies, implementing specific measures and monitoring, as well as in extensive communication and awareness raising work. The main concrete achievements of the project are presented below.

\section{Restoration of open habitats (garrigue)}

Most of the 13 bird species depend on an open habitat for nesting and / or hunting. However, in recent decades a gradual loss of open habitats has been observed, due to the abandonment of grazing activities and changing agricultural practices, as a result of which scrubland (garrigue) has become less favourable for many species, and food supply for birds has declined: insects for passerine birds like the Tawny Pipit, Dartford Warbler (Figure 8) and Ortolan Bunting; small game species such as rabbit and partridge for diurnal and nocturnal raptors.

Within the LIFE-project 170 hectares of scrubland at 12 different sites (including both private and municipal land) were cleared of dense vegetation in winter 2015 / 2016. On each site, 50-60\% of the surface vegetation was shredded with the aim of creating a mosaic of low vegetation, bushes and trees (see Figure 9). The work was preceded by quite a long preparatory phase to gather together and harmonize the requests of the many different stakeholders in the project, including land owners (private or municipalities), forest managers (French National Forest Office), hunters' organizations, livestock farmers and shepherds, as well as ornithologists and Natura 2000 site managers. Agreements with landowners and stockbreeders were signed to ensure the management of land by grazing for at least 10 years. The re-opened surfaces will be maintained by grazing sheep, goats or cattle. Grazing is also very important for the Egyptian Vulture (see Figure 3), which is a scavenger and coprophagous, feeding on small mammals, reptiles and faeces. If necessary, shredding work will be repeated every 3-5 years. In addition, the municipalities signed a commitment to preserve the natural habitat for 30 years, as

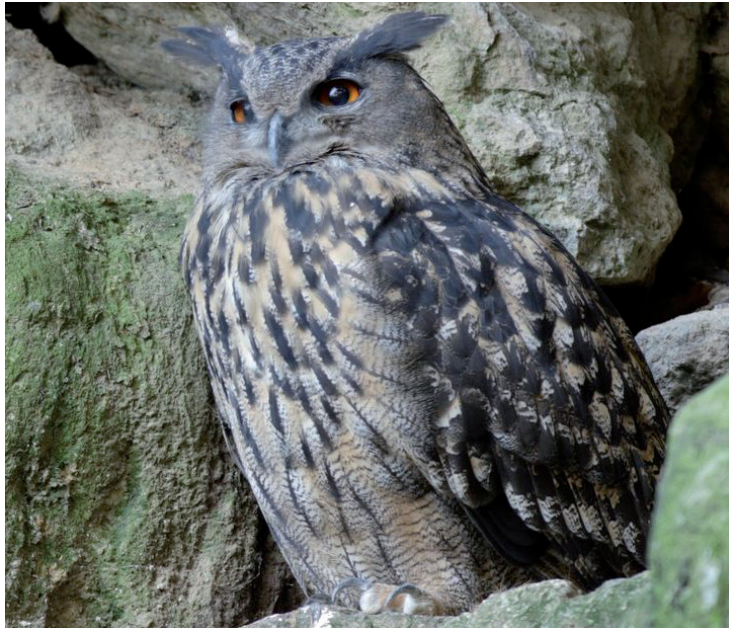

Figure 5 - Eurasian Eagle-owl - Bubo bubo (C) D. Ledan

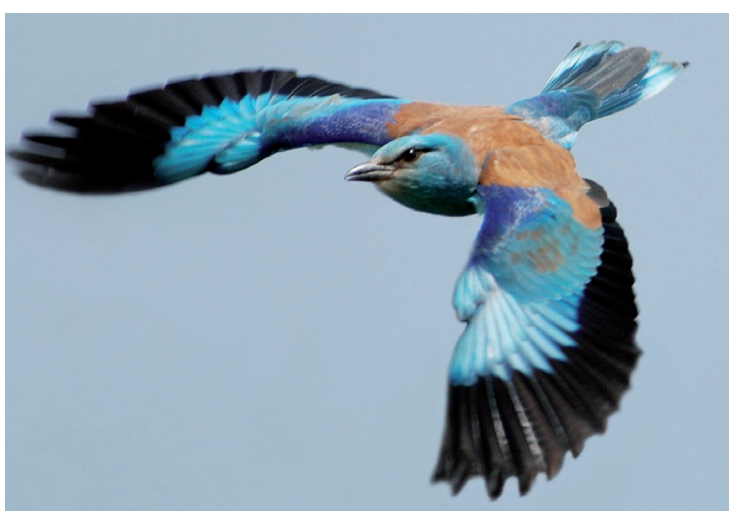

Figure 6 - European Roller - Coracias garrulus (C) $A$ Rocha France.

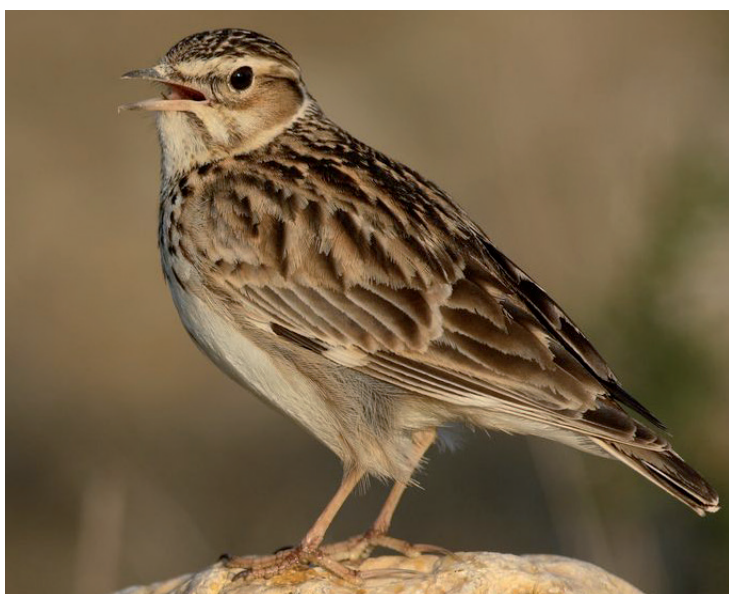

Figure 7 - Woodlark - Lullula arborea (C) D. Ledan

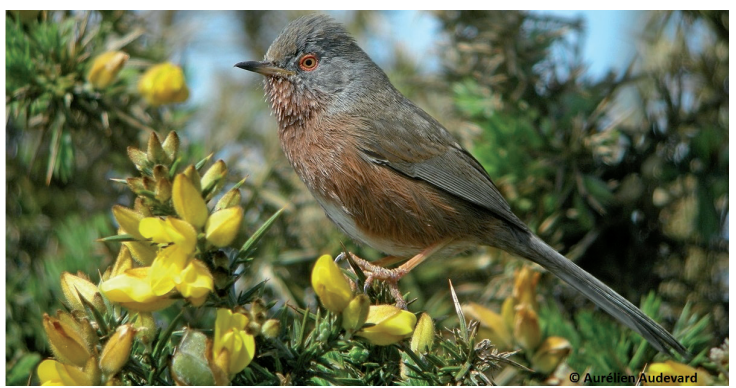

Figure 8 - Dartford Warbler - Sylvia undata (C) LPO PACA/A. Audevard 


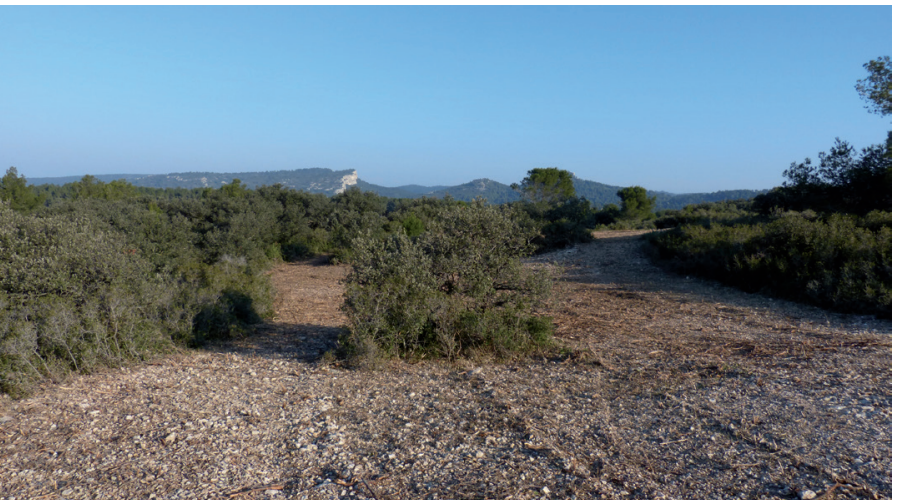

Figure 9-Restoration of garrigue. (C) Alpilles PNR/L. Zechner

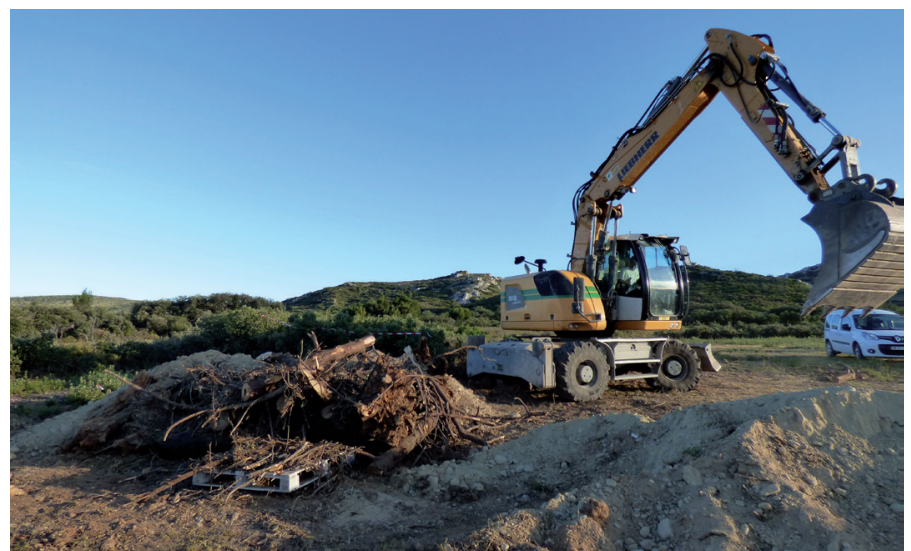

Figure 10 - Construction of rabbit warrens (C) Alpilles PNR/L. Zechner

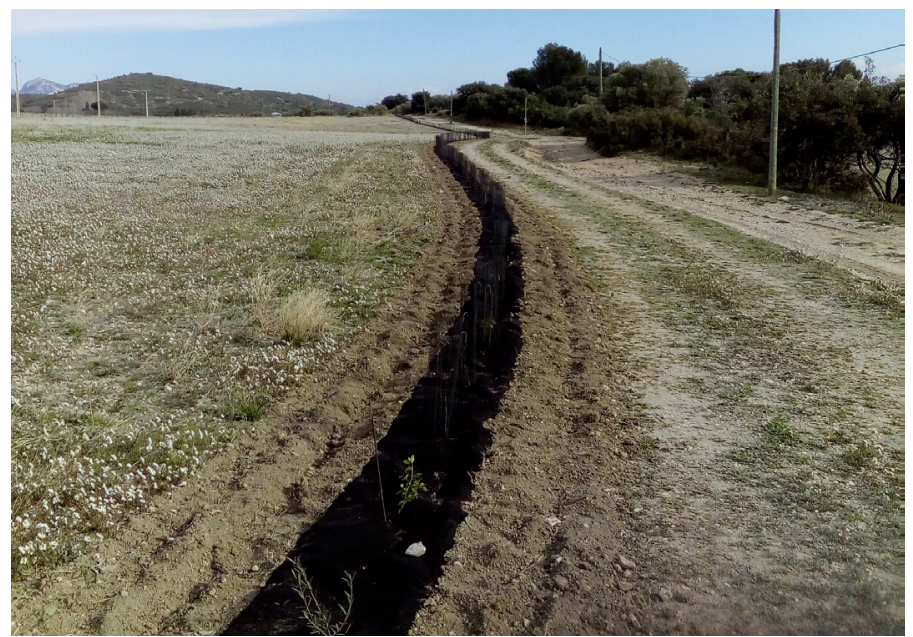

Figure 11 - Newly planted hedge (C) Alpilles PNR/L. Zechner

required by the European Commission. Furthermore, 14 hectares of small fields with diverse vegetation, and pastures for game species (Red partridge, European Rabbit) were created in February 2016, contributing further to biodiversity in the scrubland.

In the Mediterranean region, open habitats are also important as fire breaks, and therefore our actions help in fire prevention. Therefore, additional surface vegetation is shredded every year to protect houses and to secure access to the massif in case of forest fires. In combination with each other, our activities create a network of open habitats in the Alpilles.

\section{Strengthen the natural populations of prey species}

The European Rabbit and the Red-legged Partridge play an important role in the Mediterranean ecosystem as prey for large raptors like Bonelli's Eagle (Figure 1) and the Eurasian Eagle Owl (Figure 5). They are also significant game species that are traditionally hunted in the region. In recent decades, the populations of these two species have declined in the Mediterranean region, on the one hand because of a habitat change (the scrubland became denser after pastoralism was abandoned), and on the other because of diseases affecting rabbits, like myxomatosis, Hepatitis D, and rabbit haemorraghic disease.

The LIFE project carried out several initiatives to strengthen the natural populations of rabbits and RedLegged Partridge. In addition to clearing 170 hectares of scrubland in pastoral areas and the creation of small areas of grasses and meadow, 70 artificial rabbit warrens were constructed (see Figure 10), consisting of 14 complexes, each with one large central fenced warren and 4 smaller unfenced warrens nearby. Altogether 980 rabbits were released between February 2017 and February 2019.

15 cages for acclimatization of the Red Partridge prior to their release were constructed. In total, 480 birds were released during three summers (20162018). These activities were carried out in conjunction with landowners, forest managers and hunters' organizations. The hunters' organizations have signed an agreement to maintain the cages.

\section{Restoration of the hedge network}

Hedges are essential for the biodiversity of agricultural land. They fulfil environmental, agronomic, productive and landscape functions, depending on their species composition. In the Provence region, protection from the wind is one major role. Furthermore, they are also important for different bird species, for protection, nesting and feeding. Some bird species, such as the European Roller (Figure 6) or Eurasian Scops Owl, need old trees with holes for nesting. Over the past 50 years, the Natura 2000 Les Alpilles site has lost $28 \%$ of its network of hedges.

Since the beginning of the LIFE project, the hedges in the Alpilles have been studied in order to determine the state of the network and its evolution since the 1950s, and to propose actions to restore, maintain and diversify the hedges.

During the project, $6500 \mathrm{~m}$ of hedges were planted in partnership with 17 private landowners, who signed an agreement to water them for the first 2-3 years after planting and to preserve them for 30 years (see Figure 11).

The aim of developing birdlife-friendly habitats is linked to considerable awareness-raising about the multiple interests of hedges among farmers, at an ad- 
ministrative level in local small towns and villages, and among the general public. To limit future hedge removal, it is absolutely essential that people understand the important roles played by hedges.

\section{Promoting alternative farming practices}

One of the major actions of the project was the implementation of alternative farming practices in olive production, viticulture, fruit-growing and graingrowing that favour biodiversity and are economically profitable.

An inventory of the current farming practices and needs of Alpilles farmers was carried out on 40 farms. This preparatory work made it possible to identify those practices that should be promoted in the framework of training and experience-sharing days. In addition, with the assistance technicians, a dozen farmer volunteers set up plots to test alternative practices. A technical and socio-economic assessment helped to understand the obstacles and opportunities encountered. The subjects investigated were:

- the sustainable management of soil and the role of grass cover;

- the diversification of agricultural land: maintaining or planting hedges and strips of plant cover within crop fields;

- varietal choice and crop rotation: selecting varieties of wheat and companion cropping;

- alternatives to pesticides and herbicides: mechanical weeding, spraying kaolin to control the Olive Fruit Fly (development of a suitable machine to apply the kaolin; see Figure 12) and other techniques.

To encourage farmers to make these changes, it is indispensable to help them understand clearly the ecological and agronomic issues related to the practices, while linking them to the economic viability of their farms.

\section{Forest management}

Almost half of the Alpilles RNP's territory is covered by forest habitats with Aleppo pines, and scrubland (garrigue). During the LIFE project, more than 25 forest management plans for private and publiclyowned forests (managed at local municipal level) were updated to include measures for the conservation of bird species. Furthermore, the Park had drafted a guide to ecological management recommendations and organized a training session for forest landowners and local politicians.

Two concrete operations were also carried out thinning young stands of Aleppo pines (33.7 ha) on the one hand, and on the other the designation of 7 quiet zones (72.51 ha) where there will be no felling of trees for 30 years. The thinning reduces the density of trees and creates a more open habitat favourable for

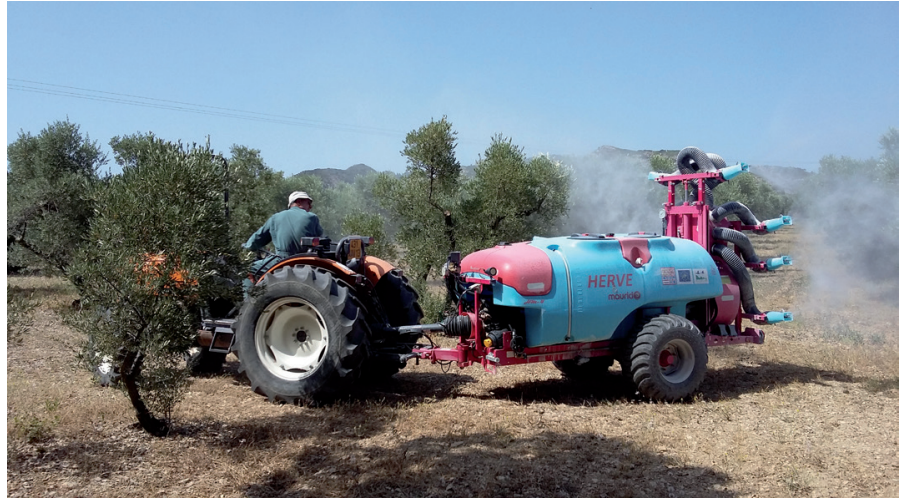

Figure 12 - Treatment of olives with kaolin against the olive fly (C) Alpilles PNR/L. Zechner

European Nightjar and Woodlark (Figure 7). The practice encourages the strongest trees to develop crowns that are suitable for the nesting of raptors such as the Short-toed Snake eagle (Figure 4). The quiet zones protect the nesting areas of the Short-toed Snake eagle and the Egyptian vulture (Figures 4 and 3).

\section{Project partners and stakeholder involvement}

Some forty actions for the benefit of the territory were carried out during the period of the project. These covered the management of all typical habitats in the Alpilles and involved establishing working relationships with many different stakeholders: the associate beneficiaries, associations, local authorities, Chambers of Commerce, Agriculture and Guilds, and educational organizations.

\section{The future}

The After LIFE conservation plan requested by the European Commission defines the continuation of the project's activities, which the Alpilles RNP will ensure by cooperating with the local partners and stakeholders listed above. For two endeavours, the conservation of hedges and the promotion of birdwatching tourism, additional French funding has already been approved, which will allow them to continue and be developed. Furthermore, the opening-up of shrubland will continue in the framework of forest fire prevention. Hopefully, these activities will contribute to the long-term preservation of the unique diversity and beauty of the Alpilles.

\section{Acknowledgements}

I would like to thank all colleagues of the Alpilles RNP for their participation in the project, especially Laetitia Baudry, Annabelle Piat and Roman Blanc for their French texts. I am also grateful to the six associated beneficiaries, local stakeholders and all partners who contributed to the realization of the project. Last 
but not least, special thanks to Adam Clark-Gimmig, who translated parts of this report.

\section{References}

Baudel, J. \& L. Zechner (in press). Un projet renforçant la gestion multifonctionnelle en Méditerranée. Le programme «LIFE des Alpilles ». Forêt méditerranéenne 3. [In French]

Campagne, C.S. \& P.K Roche 2018. May the matrix be with you! Guidelines for the application of expert-based matrix approach for ecosystem services assessment and mapping. One Ecosystem 3: e24134. doi: 10.3897/oneeco.3.e24134

Demay, J., D. Bautheac, C. Ponchon \& O. Badan 2015. Relations entre régime alimentaire et disponibilité des proies chez le grand-duc d'Europe Bubo bubo dans le massif des Alpilles depuis 30 ans. Alauda 83: 195-202. [In French]

Dupuy, J. \& A. Flitti 2014. Le Circaète Jean-le-blanc Circaetus gallicus dans la zone de protection spéciale des Alpilles (Bouches-du-Rhône) en 2014. FaunePACA publication 47: 11. [In French]

Dupuy, J. \& A. Flitti 2015. Densité et taille de population de six espèces d'oiseaux remarquables de Provence dans la Zone de Protection Spéciale des Alpilles en 2014. Faune-PACA 50: 25 [In French]
Mezier, J. \& A. Gallois 2018. Comparaison 2014/2018 des densités et tailles de populations de six espèces d'oiseaux remarquables de Provence dans la zone de protection spéciale des Alpilles. LPO PACA/ Life+ Alpilles/PNRA/A Rocha, Faune-PACA 80: $66+$ annexes. [In French]

\section{Weblinks}

Life des Alpilles: www.life-alpilles.com

Alpilles RNP: www.parc-alpilles.fr

Faune-PACA publications: https://www.faune-paca. org/index.php?m_id=20026

A Rocha France: https://france.arocha.org/fr/

CEN PACA: http://www.cen-paca.org

LPO PACA: https://paca.lpo.fr/

\section{Author}

\section{Lisbeth Zechner}

worked as project manager of the LIFE+ project Life des Alpilles. After studying zoology and management of protected areas, she worked for the National Park Gesäuse in Austria and for the Massif des Bauges and Alpilles RNPs in France. E-Mail: lisbeth_zechner@hotmail.com 